\title{
The Wonders of Nature
}

\author{
By ISABELLE POWELL, Swift Current
}

It is with regret that we read about the many changes on the prairie during the past fifty years. The vanishing Prairie Chicken, Prairie Dogs and Whooping Cranes surely they will increase again if each one would do his part in protecting them.

I was glad to see more "prairie chicken" this summer. A family of Sharp Tails came into the yard every day to feed on the wheat around the bulging granaries. How nice if more of them could benefit by this surplus wheat!

The most noticeable change at the farm the last two summers is the absence of the gopher. Some say a disease has wiped them out or they drowned in the wet weather. I recall how we fought them with poi- son to save our skimpy wheat crop in the "dirty thirties". They would have enjoyed the lush green of the wet years. However a little striped sand gopher lived in our yard all summer - its front door near the path to the garden.

The trees were full of Western Kingbirds this year-only one family last year. There are not so many Catbirds but more Brown Thrashers, flashing their bright color through the trees.

It kept us busy filling the bird bath, this long dry fall. The Barn Swallows seem to be boss here and the other sparrows and Goldfinches had to sit back and wait.

Here, in Swift Current, the robins have finished the chokecherries and are trying a few red berries on the honeysuckle bush. The Cedar Waxwings seem to like the bitter things. Maybe there is a bird tonic in them that helps them stand the cold winter, or helps in their trip farther south!

I must say how much I have enjoyed the Jubilee issues. It seems when each Blue Jay arrives, even although I have met but a few contributors, that I have had a pleasant and enlightening conversation with old friends. Come again everyone!
In all the wonders of nature there is nothing to excel camouflage. Even although man would have seemed to invent it to help win his battles, it has been going on since time began. We need only glance around the great outdoors to see how many creatures depend on camouflage for survival. Most of the moths and butterflies blend with their surroundings, as do the female birds on their nests, while the male in his brilliant colors draws attention away from the nest. The little fawn, with its dappled back, looks just like a log with the sun shining through the leaves.

On our trip to the mountains we stared a long time at a ledge high up in the Rockies before we made out the outline of a mountain goat. The Stick Caterpillar becomes rigid as a stem at the approach of danger. The Snowshoe Rabbit changes his coat with the seasons and is white when the snow comes. That funny little Measuring Worm, while wandering across a colored flower, will bite off little pieces of petals and stick them in his back when alarmed, then resumes his lunch in peace. The Tree-hopper is so much like the thorns on the stems. Many of the little fish of the ocean blend so marvelously with the seaweed as to be almost invisible.

A deer came around the trees and across the wheat field on his way to the dam for a drink. He turned broadside to stare at me, but except for the outline along his back and around his ears, his tan color blended perfectly with the ripe wheat.

Scientists say they have discovered many more universes — suns with their accompanying satelites, just like our own. No! I can't wait for a space ship! I'll call out my magic carpet and float along the milky way, and see for myself if the Big Boss has repeated his wonders of nature on the other planets throughout infinity. 